\title{
IMPLEMENTASI PROGRAM CORPORATE SOCIAL RESPONSIBILITY DI PT. INTILAND DEVELOPMENT
}

\author{
Oleh: \\ Siti Rachmawati, Moch. Zaenuddin \& Maulana Irfan \\ Email: \\ Rahmaskd@gmail.com
}

\begin{abstract}
ABSTRAK
Corporate Social Responsibility atau tanggung jawab sosial perusahaan saat ini telah diterapkan di banyak perusahaan di Indonesia. Pemerintah Indonesia telah mewajibkan perusahaan untuk melakukan program CSR. Hal ini termaktub dalam Undang-Undang Republik Indonesia no 40 tahun 2007 tentang perseroan terbatas. Program CSR yang dilaksanakan oleh perusahaan biasanya meliputi beberapa aspek, yaitu pemberdayaan komunitas, ekonomi, sosial, pengembangan kreatifitas pemuda, maupun olahraga.

Salah satu perusahaan yang menjalankan program Corporate Social Responsibility ialah PT. Intiland Development. Penelitian di perusahaan tersebut dilakukan untuk mengetahui apakah program CSR yang telah dilaksanakan oleh PT. Intiland Development menjalankan prinsip sustainable development. Mengingat pentingnya aktifitas pembangungan berkelanjutan sehingga tidak hanya dilaksanakan dalam jangka waktu singkat saja.

Penelitian ini dilakukan dengan cara studi lapangan dan juga mengkaji dari literatur terkait. Peneliti akan melakukan wawancara mendalam kepada seorang pelaksana program CSR di PT. Intiland Development. Data yang diperoleh kemudian dianalisis secara kualitatif.
\end{abstract}

\section{Abstract}

Corporate Social Responsibility or CSR has been applied in many corporates in Indonesia nowadays. Indonesia government made the rule about CSR in law no. 40 tahun 2007 about corporate. There are many kinds of CSR programs in corporate, for the example: community development, youth empowering, sports, social activity, etc. One of corporate that running CSR program is PT. Intiland Development. Researcher is going to do research in PT. Intiland because the researcher wants to know "does every CSR program in PT. Intiland using sustainable development as a principle or not". The researcher is going to do interview with the implementer of CSR in PT. Intiland and also doing investigate with some literature. After data has been collected, the data will be analysis by qualitative method.

Keywords: CSR; Sustainable development.

\section{PENDAHULUAN}

Pada umumnya, tujuan terbentuknya sebuah perusahaan adalah untuk memperoleh laba yang tinggi dan juga mempertahankan eksistensinya agar perusahaan tersebut dapat bertahan dalam jangka waktu yang lama. Pendirian perusahaan di sebuah daerah memiliki dampak positif untuk perkembangan 
daerah tersebut karena perusahaan diwajibkan membayar pajak setiap tahunnya. Selain itu juga, pendirian perusahaan dapat membuka lapangan pekerjaan sehingga masyarakat yang belum memiliki pekerjaan dapat memperoleh sumber pendapatan dari perusahaan tersebut.

Salah satu isu yang menarik dalam berjalannya aktifitas perusahaan ialah kadangkala perusahaan menggunakan sumber daya alam sebagai penunjang kegiatan perusahaannya. Dalam beberapa kasus ditemukan, terdapat perusahaan yang kurang memperhatikan keberlangsungan ekosistem di sebuah wilayah, sehingga menimbulkan kerusakan. Bukan hanya isu lingkungan, pendirian sebuah perusahaan juga seringkali menimbulkan dampak negatif dari segi sosial di sebuah masyarakat. Contohnya adalah apabila perusahaan lalai dalam mengolah limbah perusahaannya, sedangkan mayoritas profesi masyarakat di lingkungan perusahaan ialah nelayan, maka dampak tersebut sangat dirasakan oleh masyarakat karena ikan yang akan mereka tangkap telah mati disebabkan oleh limbah berbahaya tersebut.

Pada tahun 2007 pemerintah Indonesia berupaya mengeluarkan undang-undang tentang Corporate Social Responsibility (CSR) yang tertera dalam UU No. 40 tahun 2007 pasal 64 yang mengatakan perusahaan yang menjalankan kegiatan usaha dibidang atau berkaitan dengan sumber daya alam wajib melaksanakan tanggung jawab sosial dan lingkungan.

\section{PUSTAKA}

ISO 26000 memberikan definisi CSR dalam Guidance on Social Responsibility, bahwa CSR adalah tanggungjawab sebuah organisasi terhadap dampak-dampak dari keputusan-keputusan dan kegiatankegiatannya pada masyarakat dan lingkungan

\footnotetext{
${ }^{3}$ Edi, Suharto, Pekerjaan Sosial di Dunia Industri Memperkuat Tanggungjawab Sosial Perusahaan, Bandung, PT. Refika Aditama, 2007

${ }^{4}$ Tri Budiyono, Hukum Perusahaan, (Salatiga: Griya Media, 2011)
}

yang diwujudkan dalam bentuk perilaku transparan dan etis yang sejalan dengan pembangunan berkelanjutan dan kesejahteraan masyarakat; mempertimbangkan harapan pemangku kepentingan, sejalan dengan hukum yang ditetapkan dan norma-norma perilaku internasional; serta integrasi dengan organisasi secara menyeluruh (draft 3, 2007) ${ }^{3}$ Dalam definisi tersebut dapat diartikan bahwa perusahaan/organisasi tidak dapat berdiri sendiri karena mereka memiliki tanggungjawab terhadap lingkungan dan masyarakat sekitar. Selain itu, perusahaan juga harus turut berkontribusi untuk melakukan pembangunan yang berkelanjutan.

Konsep Corporate Social Responsibility muncul pada tahun 1900-an berawal dari konsep kekayaan di Amerika Serikat. Seorang pendiri perusahaan U.S Steel, Andrew Carnegie menerbitkan buku yang berjudul The Gospel of Wealth, yang mengemukakan tentang pendapat klasik tentang tanggung jawab perusahaan. Disebutkan bahwa Ia memiliki 2 prinsip dasar yaitu prinsip amal dan prinsip mengurus harta orang lain.

Beragam istilah yang sepadan dengan CSR misalnya Corporate Responsibility, Corporate Citizenship, Responsible Business, Sustainable Responsible Business, dan Corporate Social Performance ${ }^{4}$. Namun menurut bahasa, Corporate Social Responsibility (CSR) berarti tanggungjawab sosial perusahaan.

Terdapat tujuh hal yang menjadi komponen utama tanggung jawab sosial perusahaan/ CSR menurut Wibisono ${ }^{5}$ yaitu antara lain sebagai berikut:

1. Perlindungan lingkungan: Perlindungan lingkungan dilakukan perusahaan sebagai

\footnotetext{
${ }^{5}$ Komponen CSR, http://www.scribd.com/doc/106543823/KomponenCsr
} 
wujud kontrol sosial yang berfokus pada pembangunan berkelanjutan.

2. Perlindungan dan jaminan karyawan: Kesejahteraan karyawan merupakan hal mutlak yang menjadi tolak ukur bagi perusahaan dalam menghargai karyawannya.

3. Interaksi dan keterlibatan perusahaan dengan masyarakat: Peran masyarakat dalam menentukan kebijakan perusahaan penting, sehingga perusahaan dengan masyarakat sekitarnya harus menjaga harmonisasi agar bersinergi.

4. Kepemimpinan dan pemegang saham: Pemegang saham merupakan pihak yang paling memiliki kepentingan terhadap pencapaian keuntungan yang diperoleh perusahaan.

5. Penanganan produk dan pelanggan: Kepuasan pelanggan adalah hal yang utama, sehingga apabila pelanggan puas maka mereka akan repeat order dan keuntungan lebih akan diperoleh.

6. Pemasok (supplier) : Pemasok merupakan pihak yang menguasai jaringan distribusi.Hubungan yang baik dengan pemasok menguntungkan perusahaan.

7. Komunikasi dan laporan: Keterbukaan terhadap komunikasi dan pelaporan yang tercermin melalui sestem informasi akan membantu dalam pengambilan keputusan. Diperlukan keterbukaan informasi material dan relevan bagi stakeholders.

Selain Undang-undang yang mewajibkan perusahaan menjalankan CSR, terdapat beberapa motivasi lain yang menjadi alasan mengapa perusahaan melaksanakan tanggung jawab perusahaan.

Saidi dan abidin (2004:69) membuat matriks yang menggambarkan tiga tahap atau pradigma yang berbeda. Tahap pertama adalah corporate charity, yakni dorongan amal

6

http://www.policy.hu/suharto/Naskah\%20PDF/PSICSR ComDev.pdf berdasarkan motivasi keagamaan. Tahap kedua adalah corporate philantrophy, yakni dorongan kemanusiaan yang biasanya bersumber dari norma dan etika universal untuk menolong sesame dan memperjuangkan pemerataan sosial. Tahap ketiga adalah corporate citizenship, yaitu motivasi kewargaan demi mewujudkan keadilan sosial berdasarkan prinsip keterlibatan sosial. Jika dipetakan, tampaklah bahwa spectrum pradigma ini terentang dari "sekedar menjalankan kewajiban" hingga "demi kepentingan bersama" atau dari "membantu dan beramal kepada sesama" menjadi "memberdayakan manusia"6.

Kebijakan program CSR juga diwajibkan bagi perusahaan dalam rangka penanaman modal. Kewajiban tersebut diatur dalam UU No. 25 tahun 2007 pasal 15 ayat B yang menegaskan setiap penanam modal berkewajiban melaksanakan tanggung jawab sosial perusahaan (CSR) dan pasal 16 ayat D mengatakan setiap penanaman modal bertanggung jawab menjaga kelestarian lingkungan. Artinya perusahaan penanaman modal berkewajiban memprogramkan kegiatan CSR sehingga dapat meningkatkan jaminan kelangsungan aktivitas perusahaan karena adanya hubungan yang serasi dan saling ketergantungan antara pengusaha dan masyarakat (Firdaus Abdullah, 2011)

Meskipun begitu, terdapat kelompok yang berasal dari akademisi ataupun pebisnis yang menolak dengan konsep CSR. Mereka memiliki argumen bahwa perusahaan adalah organisasi perncari laba dan bukan perorangan atau sekumpulan orang seperti halnya dalam organisasi sosial. Bukankah perusahaan telah membayar pajak kepada negara dan karena tanggungjawabnya untuk meningkatkan kesejahteraan publik telah diambil alih pemerintah? (Saidi dan Abidin, 2004). Namun alasan tersebut tidak patut dijadikan alasan bahwa perusahaan tidak perlu melaksanakan CSR. Terlebih Indonesia menganut residual 
welfare state, manfaat pajak sering tidak sampai kepada masyarakat, terutama kelompok lemah dan rentan. Akibatnya, sebagian besar dari mereka hidup tanpa perlindungan sosial yang memadai. (Suharto, 2007).

Meskipun pelaksanaan tanggung jawab sosial perusahaan/CSR dianggap tidak menguntungkan dari segi ekonomis, namun apabila dilakukan dengan benar, terstruktur, dan bersifat jangka panjang bukan hal yang mustahil jika kegiatan tersebut dapat memberikan keuntungan ekonomis bagi perusahaan serta mendapatkan kepercayaan bagi konsumen/stakeholder.

Namun bagaimanakah indikator CSR yang sukses dalam sebuah perusahaan? Menurut Suharto dalam buku Pekerjaan Sosial di Dunia Industri (2007), CSR tidak hanya fokus pada hasil yang dicapai. Melainkan pula pada proses untuk mencapai hasil tersebut. Proses tersebut ialah engagement: membangun pemahaman, penerimaan, dan trust pada masyarakat yang akan dijadikan sasaran CSR; Assessment: Mengidentifikasi masalah yang akan dijadikan dasar dalam merumuskan program; Plan of action: Merumuskan rencana aksi dan program tersebut sebaiknya memperhatikan aspirasi masyarakat (stakeholders); Action and Facilitation: Penerapan program baik mandiri oleh masyarakat, bersama perusahaan, atau difasilitasi oleh LSM; Evaluation and termination or reformation: menilai sejauh mana keberhasilan pelaksanaan program CSR di lapangan. Menurut saidi dan abidi (2004: 64-65) sedikitnya ada empat model atau pola CSR yang umumnya diterapkan di Indonesia 1. Keterlibatan langsung, Perusahaan menjalankan program CSR secara langsung dengan menyelenggarakan sendiri kegiatan sosial atau menyerahkan sumbangan ke masyarakat tanpa perantara. Untuk menjalankan tugas ini, sebuah perusahaan biasanya menugaskan salah satu pejabat sniornya, seperti corporate secretary atau public affair manager atau menjadi bagian dari tugas pejabat public relation. 2. Melalui yayasan atau organisasi sosial perusahaan,
Perusahaan mendirikan yayasan sendiri di bawah perusahaan atau groupnya. Model ini merupakan adopsi dari model yang lazim diterapkan di perusahaan-perusahaan di Negara maju. Biasanya perusahaan menyediakan dana awal, dan rutin atau dana abadi yang dapat digunakan secara teratur bagi kegiatan yayasan. Beberapa yayasan yang didirikan perusahaan diantaranya adalah yayasan coca cola company, yayasan riot into (perusahaan pertambangan), yayasan dharma bhakti astra, yayasan sahabat aqua, GE Fund. 3. Bermitra dengan pihak lain Perusahaan menyelenggarakan CSR melalui kerjasama dengan lembaga sosial/organisasi nonpemerintah, instansi pemerintah, universitas atau media massa, baik dalam mengelola dana maupun dalam melaksanakan kegiatan sosialnya. Beberapa lembaga sosial/organisasi non-pemerintah yang bekerjasama dengan perusahaan dalam menjalankan CSR antara lain adalah (PMI, Yayasan Kesejahteraan Anak Indonesia, Dompet Dhuafa) instansi pemerintah (lembaga ilmu pengetahuan Indonesia, Depdiknas, Depkes, Depsos), universitas (UI,ITB,IPB), media massa (Kompas,kita peduli indosiar) 4. Mendukung atau bergabung dalam suatu konsorsium Perusahaan turut mendirikan, menjadi anggota atau mendukung suatu lembaga sosial yang didirikan untuk tujuan sosial tertentu. Dibandingkan dengan model lainnya, pola ini lebih berorientasi pada pemberian hibah perusahaan yang bersifat "hibah pembangunan". Pihak konsorsium atau lembaga semacam itu yang dipercayai oleh perusahaan-perusahaan yang mendukungnya secara pro aktif mencari mitra kerjasama dari kalangan lembaga operasional dan kemudian mengembangkan program yang disepakati bersama. Jadi program tanggung jawab sosial yang dilaksanakan di sebuah perusahaan, tidak selalu dijalankan oleh perusahaan sendiri, melainkan juga mengajak kerja sama beberapa organisasi terkait ataupun juga mengandalkan organisasi yang sudah berpengalaman untuk melakukan assessment. 


\section{PENUTUP}

Perusahaan yang turut menjalankan program Corporate Social Responsibility adalah perusahaan yang bergerak di bidang properti. Perusahaan properti merupakan salah satu perusahaan yang memanfaatkan sumber daya alam. Perusahaan ini menggunakan tanah di suatu daerah untuk pembangunan dan juga

\section{Daftar Pustaka}

Edi, Suharto, Pekerjaan Sosial di Dunia Industri Memperkuat Tanggungjawab
Sosial Perusahaan, Bandung, PT. Refika Aditama, 2007

Komponen CSR, http://www.scribd.com/doc/106543823/ Komponen-Csr

Tri Budiyono, Hukum Perusahaan, (Salatiga: Griya Media, 2011)

http://www.policy.hu/suharto/Naskah\%20PD F/PSICSRComDev.pdf 